$1-1-1982$

\title{
An assessment of transportation services by older citizens in Doddridge, Hampshire, and Webster counties, West Virginia, in 1978
}

Kenneth D. McIntosh

Follow this and additional works at: https://researchrepository.wvu.edu/ wv_agricultural_and_forestry_experiment_station_bulletins

\section{Digital Commons Citation}

McIntosh, Kenneth D., "An assessment of transportation services by older citizens in Doddridge, Hampshire, and Webster counties, West Virginia, in 1978" (1982). West Virginia Agricultural and Forestry Experiment Station Bulletins. 680.

https://researchrepository.wvu.edu/wv_agricultural_and_forestry_experiment_station_bulletins/575 @ WVU. It has been accepted for inclusion in West Virginia Agricultural and Forestry Experiment Station Bulletins by an authorized administrator of The Research Repository @WVU. For more information, please contact ian.harmon@mail.wvu.edu. 


\section{An Assessment of Transportation Services By Older Citizens in Doddridge, Hampshire, and Webster Counties, West Virginia, in 1978}

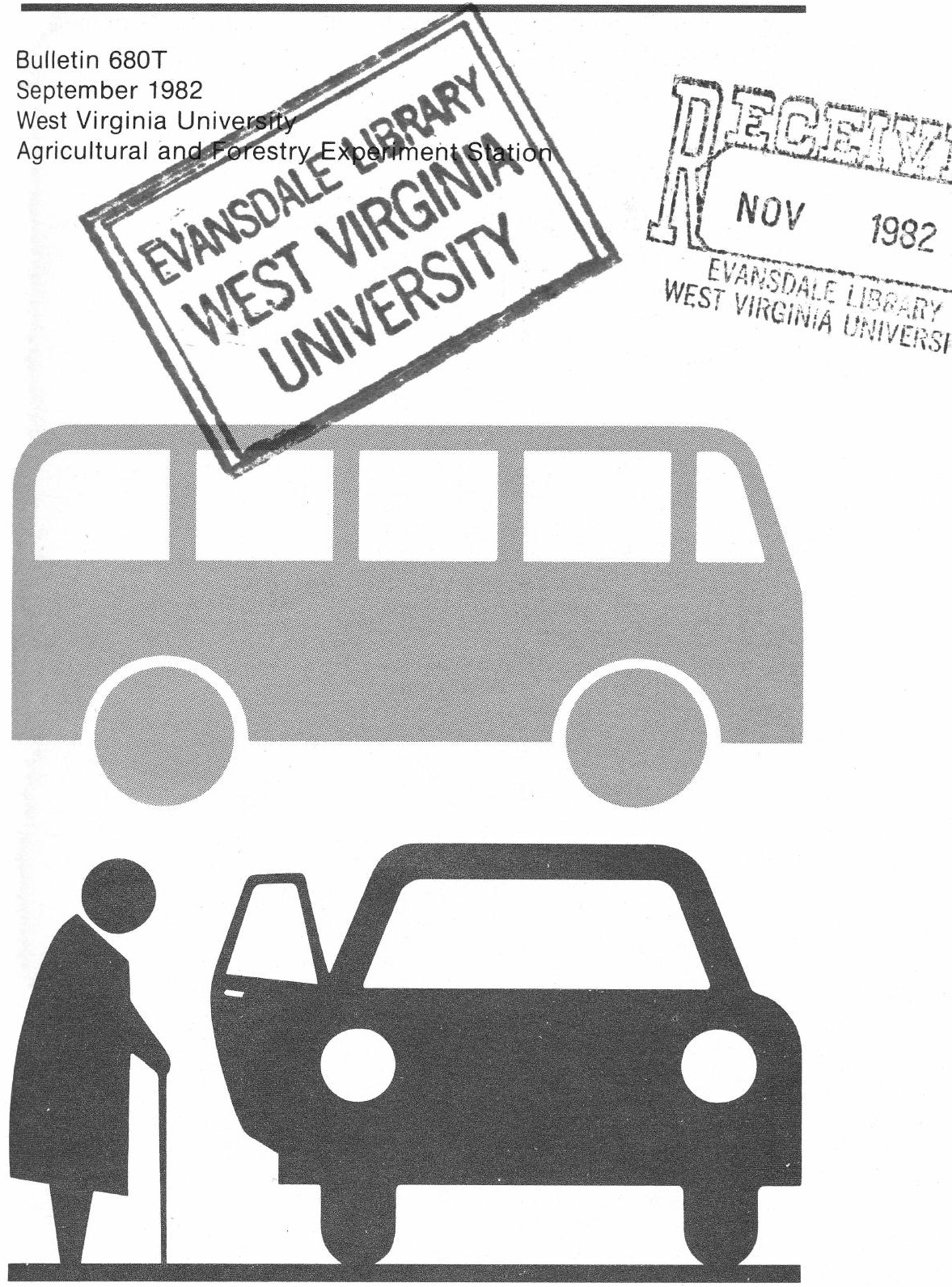




\section{Author}

Kenneth D. Mclntosh is Professor of Agricultural Economics and Economics

\section{Acknowledgments}

The author extends thanks to Dr. L. M. Sizer and to the several enumerators and graduate students who assisted in the interviewing of older citizens. Special thanks to Dale Cunningham, Kathy Reger, and Judith Starr for their close attention to data collection and editing.

\section{Abstract}

The results of a sample survey of older heads of households in three rural counties of West Virg inia indicate that 80 percent do not perceive any transportation problems. Households headed by single females have more transportation problems than other types of households. Transportation problems increase among those who do not drive.

Approximately one-half of the respondents drive their own cars and one-third relied upon relatives and friends for their transportation needs. The informal transportation networks are quite important to older citizens in rural West Virginia. Less than 5 percent of those interviewed used public transportation when travelling to town. Another 10 percent walked to town and the remainder hitchhiked, borrowed a car, or seldom went to town.

West Virginia University

Agricultural and Forestry Experiment Station

College of Agriculture and Forestry

Dale W. Zinn, Director

Morgantown 


\section{Contents}

Abstract........................ inside front cover

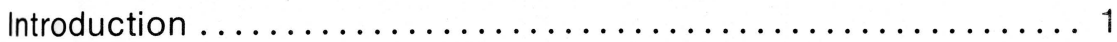

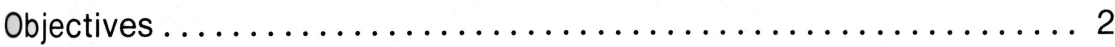

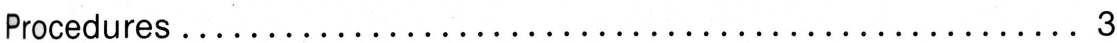

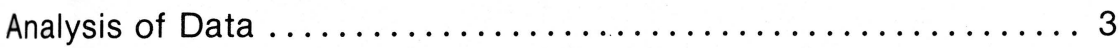

Summary, Conclusions and Speculations .............. 14 
Blank Page in Original Bulletin 


\title{
An Assessment of Transportation Services By Older Citizens in Doddridge, Hampshire, and Webster Counties, West Virginia, in 1978
}

\author{
Kenneth D. Mclntosh
}

\section{Introduction}

For the past twenty years residents in rural areas of West Virginia have been confronted with generally increasing costs and declining quality of public transportation service. ${ }^{1}$ In many areas of the state private bus lines have closed operations or curtailed services through reduced trip schedules or a reduced number of routes. ${ }^{2}$ Counties and communities with low population densities have been especially pressed to maintain bus services. In the more rural and isolated areas, taxi services have always been costly and all too often not available at any price. Of the licensed taxis in West Virginia, ten counties had none and eight counties had one taxi, while ten counties had 57 percent of the taxicabs. ${ }^{3}$ In recent years cab fares have been increased to offset rising costs of operations and this method of rural transportation is becoming relatively expensive for many rural residents.

Declining transportation services are of special concern to the older citizens in rural areas. Physical disabilities which increase with age reduce the driving ability of many senior citizens and make them more dependent upon public transportation or private transport by relatives and friends. For some, physical disabilities are so great that special transportation services are also required whenever they travel, e.g., buses equipped for wheelchair riders. Thus, in areas not serviced by buses or taxis many elderly citizens face extreme difficulty if friends, neighbors, or relatives do not provide transportation assistance. The Department of Welfare provides transportation services for a number of low income elderly but the extent of such assistance is not known.

In some areas, the county government has established bus transportation systems that partially service rural areas. Inadequate funds, legal requirements, and lack of public support impinge upon the ability of county

\footnotetext{
'For an excellent review of the transportation difficulties in rural America see, Transportation in Rural America, An Analysis of the Current Crisis in Rural Transportation, 94th Congress, 1st Session, U.S. Senate Report, Committee on Agriculture and Forestry, U.S. Government Printing Office, February 19, 1975.

'Specific transportation circumstances as observed by people throughout West Virginia can be noted in Older Americans in Rural Areas, 91st Congress, 2nd Session, U.S. Senate Special Committee on Aging, U.S Government Printing Office, 1971.

UU.S Bureau of the Census, 1972 National Transportation Report: Present Status-Future Alternatives, July 1, 1972.
} 
governments to provide adequate transportation services in all rural areas. The major source of capital for these systems has been federal grants or federal revenue sharing funds. While local governments have been providing some financial assistance, it has been limited and problems will intensify if federal and state support is withdrawn.

For several years rural transportation in West Virginia has been subsidized through the TRIP program, ${ }^{4}$ but recently there has been increasing resistance to the expenditure of public funds for such purpose. Initially, the federal government provided grant funds to the state for a demonstration type research effort to assess the feasibility of public transportation services in rural areas. When the federal financing expired, the West Virginia state legislature provided temporary funding. Subsequently, the governor's office provided funding when the appropriations from the legislature had been used. ${ }^{5}$ Currently, there is no statutory provision for continued public funding and the future course of subsidized rural transportation in West Virginia is unclear.

The TRIP program was intended for all persons in rural areas. Thus, while older citizens in rural areas may benefit, indeed may even be the primary beneficiaries of TRIP, it is unlikely that the program could have been justified simply on the basis of use by senior citizens. The older age groups account for a significant proportion of the rural population but the population is widely dispersed with low densities in some areas. ${ }^{6}$ Under these conditions it may be difficult to obtain sufficient riders of all ages to economically support a bus system, be it privately or publicly owned and operated. Added to the basic population problem is the seeming preference of individuals to service their own transportation needs with privately owned cars.

Over the past ten years, U.S. congressional reports have detailed the serious state of affairs with respect to transportation in rural America. ${ }^{7}$ In general, they indicate that rural transportation systems suffer from a host of problems including capital requirements, low ridership, scheduling problems, and bad roads. In turn, these lead to high cost operations and explain why rural transportation systems are under continual financial stress. However, these reports are less clear concerning the utilization of transportation systems by older citizens. In fact, very few focus on the elderly and their perceptions of needs for transportation services.

\section{Objectives}

Under the above circumstances it appeared appropriate that basic information on transportation needs of the elderly in rural areas be assessed by conducting personal interviews with older citizens. What is the frequency of

\footnotetext{
${ }^{4}$ West Virginia Department of Welfare, Transportation Remuneration Incentive Program: Development Plan, Charleston, W. Va. 1973.

${ }^{5}$ This sequence of events was explained by Barry Goldberg. Assistant to the Monongalia County Commission.
}

6 U.S. Bureau of the Census, Census of Population: 1970, Final Report PC(1)-C50 West Virginia, 1973.

${ }^{7}$ These reports include: Family Farms and Rural Development, U.S. House of Representatives, Agriculture Committee, October, 1974; Transportation of People in Rural Areas, U.S. Senate Report February, 1974; Transportation in Rural Areas, U.S. Senate Report, February, 1975; and Hearings before the U.S. Senate Special Committee on Aging in October, 1970, in Clarksburg and Dogbone, W. va. 
travel to town? Are senior citizens confronted with transportation problems? If so, what is the nature of such problems and what suggestions do they have for resolving them? In short, this research effort was devised, in part, to ascertain basic data about transportation service needs confronting senior citizens in three rural counties of West Virginia.

\section{Procedures}

To assess the availability and needs for various public services, a sample of elderly persons was interviewed in Doddridge, Hampshire, and Webster counties during the summer of 1978. These counties are classified as 100 percent rural by the Bureau of the Census. ${ }^{8}$ There were 325 heads of households in the sample and personal interviews were conducted with each one. For additional information on the selection of sample, interviewing, sample size, etc., see Mclntosh and Sizer. ${ }^{9}$

\section{Analysis of Data}

On the basis of a simple tabulation of responses from this sample, one might conclude that the elderly in rural areas really have few transportation problems (Table 1). Approximately 80 percent indicated that they did not consider

\section{Table 1}

"When you go to town is transportation considered to be a problem?" Responses from Sample of Elderly Household Heads in Hampshire, Doddridge, and Webster Counties, West Virginia, 1978.

\begin{tabular}{lrr}
\hline Nature of Problem & Number & Percent \\
\hline Serious & 14 & 4.3 \\
Sometimes a problem & 52 & 16.0 \\
No problem & 257 & 79.1 \\
No response $\quad 2$ & 0.6 \\
$\quad$ Totals & 325 & 100.0 \\
\hline
\end{tabular}

transportation to be a problem. Of those who did view it as a problem, only one in five deemed it serious. Obviously, the seriousness of transportation problems depends upon individual needs for such service as well as availability and cost. If a person must go to town daily or weekly and there is no public transportation and he cannot provide his own transportation for physical reasons, there is indeed a problem. On the other hand, someone who travels to

\footnotetext{
${ }^{8}$ For detailed descriptions and definitions of rural and urban populations see: U.S. Bureau of the Census, Census of Population: 1970, Final Report PC(1)-C50 West Virginia, Appendix A, 1973.

${ }^{9}$ Housing Conditions of Older Citizens in Three Rural Counties of West Virginia, Mclntosh, K. D. and Sizer, L. M., West Virginia Agricultural and Forestry Experiment Station, Resource Management Series No. 79, February, 1980.
} 
town monthly and who lives along a road where bus service is available daily, may laugh at the suggestion of transportation problems. Indeed, he might well comment on unnecessary government expenditures if he is providing his own transportation.

There are five types of categories of households in this study, and when these are cross tabulated with transportation problems a relationship is noted (Table 2). Households headed by single females or an aged head with non-filial relatives have more problems with transportation than those headed by an aged head with a spouse or those headed by an aged head with filial members living in the house.

\section{Table 2}

Incidence of Transportation Problems and Type Household, Sample of Elderly Household Heads in Doddridge, Hampshire, and Webster Counties, West Virginia, 1978.

Type of Household

Incidence of Transportation Single Single Aged Head Aged Head with Other Problems Male Female and Spouse with Family Relatives

Totals

\begin{tabular}{lrrrrrr}
$\begin{array}{l}\text { Serious } \\
\quad \text { Problems }\end{array}$ & 2 & 3 & 6 & 0 & 3 & 14 \\
$\begin{array}{l}\text { Some } \\
\text { Problem }\end{array}$ & 5 & 20 & 10 & 6 & 11 & 52 \\
No Problem & 29 & 61 & 107 & 31 & 29 & 257 \\
$\quad$ Totals & 36 & 84 & 123 & 37 & 43 & 323 \\
\hline
\end{tabular}

Chi square $=15.325$ with 8 degrees of freedom. . . significance $=0.053$. In this and all other Chi square tests in this bulletin, significance indicates the level where the computed chi square value is considered statistically significant. e.g., the 15.325 computed chi square value is significant at the 5 percent probability level.

Finally, if a level of government provides daily transportation services in thinly populated rural areas, the citizens in such areas may not have transport problems but the service may be at a relatively high cost. Thus, one must be cautious when interpreting or reflecting upon the aggregate data that indicate some 80 percent of the older population in rural areas have no transportation problems.

From other views, one might conclude that older residents do not perceive transportation problems because (1) they drive their own cars, (2) use public transportation, (3) do not travel distances requiring transportation, or (4) obtain private transportation from friends, relatives, and neighbors. When these are checked with tabulated sample data one notes that 60 percent owned a car (Table 3), and three-fourths of these cars where less than ten years old (Table 4). Seventy percent of those who did not own a car indicated that they 
Table 3

Car Ownership by a Sample of Elderly Household Heads in Doddridge, Hampshire, and Webster Counties, West Virginia, 1978.

\begin{tabular}{lcc}
\hline \hline Response & Number & Percent \\
\hline Yes & 195 & 60.0 \\
No & 129 & 39.7 \\
No Response & 1 & 0.3 \\
$\quad$ Totals & 325 & 100.0 \\
\hline
\end{tabular}

\section{Table 4}

Age of Car Owned by a Sample of Elderly Household Heads in Doddridge, Hampshire, and Webster Counties, West Virginia, 1978.

\begin{tabular}{lrr}
\hline \hline Age of Cars (Years) & $\begin{array}{c}\text { Number of } \\
\text { Household Heads }\end{array}$ & Percent \\
\hline 1 & 3 & 1.54 \\
2 & 22 & 11.28 \\
3 & 14 & 7.18 \\
4 & 15 & 7.69 \\
5 & 15 & 7.69 \\
6 & 23 & 11.79 \\
7 & 21 & 10.77 \\
8 & 14 & 7.18 \\
9 & 16 & 8.21 \\
$10-13$ & 31 & 15.90 \\
$14+$ & 18 & 9.23 \\
Not Known & 3 & 1.54 \\
\multicolumn{1}{c}{ Totals } & 195 & 100.00 \\
\hline
\end{tabular}

did not drive (Table 5). In spite of commonly held opinions about the financial stringencies of the elderly only 6 percent of those without cars indicated that expenses were the primary reason why a car was not owned (Table 5). Quite simply, if one does not drive, the ownership of a car may not always make practical or economic sense.

When asked, "When you go to town or other places how do you get there?" approximately half of the sample noted that they usually used their own cars (Table 6). Another 5 percent sometimes used their cars. When the type of household was cross tabulated with driving their own car a highly significant 


\section{Table 5}

Reasons for not Owning a Car Given by a Sample of Elderly Household Heads in Doddridge, Hampshire, and Webster Counties, West Virginia, 1978.

\begin{tabular}{lcc}
\hline \hline Reasons & Number & Percent \\
\hline Too expensive & 8 & 6.20 \\
Do not drive & 90 & 69.77 \\
Other reasons & 28 & 21.70 \\
No response & 3 & 2.33 \\
Totals & 129 & 100.00 \\
\hline
\end{tabular}

\section{Table 6}

Mode of Traveling to Town for a Sample of Elderly Household Heads in Doddridge, Hampshire, and Webster Counties, West Virginia, 1978.

\begin{tabular}{|c|c|c|c|c|c|c|}
\hline \multirow[b]{3}{*}{ Mode of Travel } & \multicolumn{6}{|c|}{ Frequency of Using Travel Mode } \\
\hline & \multicolumn{2}{|c|}{ Usually - } & \multicolumn{2}{|c|}{ Sometimes } & \multicolumn{2}{|c|}{ Never } \\
\hline & No. & $\%$ & No. & $\%$ & No. & $\%$ \\
\hline Drive own car & 160 & 49.2 & 17 & 5.2 & 147 & 45.7 \\
\hline Borrow a car & 2 & 0.6 & 12 & 3.7 & 310 & 95.4 \\
\hline Walk & 30 & 9.2 & 54 & 16.6 & 240 & 73.9 \\
\hline Hitchhike & 1 & 0.3 & 6 & 1.9 & 317 & 97.5 \\
\hline Public transportation & 9 & 2.87 & 49 & 15.1 & 266 & 81.9 \\
\hline $\begin{array}{l}\text { Ride with household } \\
\text { members }\end{array}$ & 33 & 10.2 & 76 & 23.4 & 215 & 66.2 \\
\hline $\begin{array}{l}\text { Ride with other } \\
\text { relatives or friends }\end{array}$ & 76 & 23.4 & 177 & 54.5 & 71 & 21.9 \\
\hline
\end{tabular}

relationship was discerned (Table 7). Single females who are heads of household or aged heads who live with non-filial relatives rarely drive themselves to town. This is not unexpected since car ownership is relatively low among single females and males who live with relatives other than immediate family members.

A third of the sample usually rode with others in the household or with family members, friends, relatives, and neighbors. In addition, nearly 80 percent indicated that they sometimes relied upon this informal transportation system.

When the type of household is cross tabulated against riding with others in the household and with others not in the household (Tables 8 and 9), additional insight is provided concerning informal transportation networks. Heads bf 


\section{Table 7}

Driving Oneself to Town by Type of Houeshold for the Sample of Elderly Household Heads in Doddridge, Hampshire, and Webster Counties, West Virginia, 1978.

\begin{tabular}{|c|c|c|c|c|c|c|}
\hline $\begin{array}{l}\text { Driving Onese } \\
\text { to Town }\end{array}$ & $\begin{array}{l}\text { Single } \\
\text { Male }\end{array}$ & $\begin{array}{l}\text { Single } \\
\text { Female }\end{array}$ & $\begin{array}{l}\text { Aged Head } \\
\text { and Spouse }\end{array}$ & $\begin{array}{l}\text { Aged Head } \\
\text { with Family }\end{array}$ & $\begin{array}{c}\text { Aged Head } \\
\text { with Other } \\
\text { Relatives }\end{array}$ & Totals \\
\hline Usually & 22 & 18 & 84 & 26 & 10 & 160 \\
\hline Sometimes & 2 & 4 & 5 & 3 & 3 & 17 \\
\hline Never & 12 & 62 & 34 & 8 & 31 & 147 \\
\hline Totals & 36 & 84 & 123 & 37 & 44 & 324 \\
\hline
\end{tabular}

Chi square $=69.30$ with 8 degrees of freedom. . . significance $=0.0001$.

\section{Table 8}

Household Type Cross Tabulated with Riding to Town with Others in the Household, Sample of Elderly Household Heads in Doddridge, Hampshire, and Webster Counties, West Virginia, 1978.

Type of Household

Ride to Town

$\begin{array}{lll}\text { Ride to Town } & \text { Aged Head } \\ \text { with Others in Single Single Aged Head Aged Head with Other }\end{array}$ the Household Male Female and Spouse with Family Relatives Totals

\begin{tabular}{lrrrrrr}
\hline Usually & 0 & 0 & 18 & 5 & 10 & 33 \\
Sometimes & 0 & 0 & 41 & 17 & 17 & 75 \\
Never & 36 & 84 & 64 & 15 & 17 & 216 \\
\multicolumn{1}{c}{ Totals } & 36 & 84 & 123 & 37 & 44 & 324 \\
\hline
\end{tabular}

Chi square $=97.51$ with 8 degrees of freedom. . . significance 0.0001 .

households who live with children place considerable reliance upon these household members to provide transportation when they go to town. Furthermore, they place equal reliance upon the provision of transportation by non-filial relatives, friends, and neighbors who live nearby. In households with an aged male head and spouse, the spouse often does the driving when they go to town. However, even in these households there is considerable reliance upon friends, relatives, and neighbors for transportation to town. Households headed by single females have unusually heavy dependence upon the informal transportation networks when they go to town (Table 9).

The information in Table 6 underscores clearly the transportation options and dilemma confronting those who reside in rural areas of the state. One must either provide his own transportation or enter into informal arrangements with 


\section{Table 9}

Riding to Town with Others Cross Tabulated with Type Household, Sample of Elderly Household Heads in Doddridge, Hampshire, and Webster Counties, West Virginia, 1978.

Type of Household

\begin{tabular}{|c|c|c|c|c|c|c|}
\hline $\begin{array}{l}\text { Riding to Town } \\
\text { with Others }\end{array}$ & $\begin{array}{l}\text { Single } \\
\text { Male }\end{array}$ & $\begin{array}{l}\text { Single } \\
\text { Female }\end{array}$ & $\begin{array}{l}\text { Aged Head } \\
\text { and Spouse }\end{array}$ & $\begin{array}{l}\text { Aged Head } \\
\text { with Family }\end{array}$ & $\begin{array}{c}\text { Aged Head } \\
\text { with Other } \\
\text { Relatives }\end{array}$ & Totals \\
\hline Usually & 10 & 34 & 19 & 1 & 12 & 76 \\
\hline Sometimes & 18 & 45 & 68 & 19 & 27 & 177 \\
\hline Never & 8 & 5 & 36 & 17 & 5 & 71 \\
\hline Totals & 36 & 84 & 123 & 37 & 44 & 324 \\
\hline
\end{tabular}

Chi square $=46.49$ with 8 degrees of freedom. . .significance $=0.0001$.

friends, relatives, or neighbors for transportation to town. According to the respondents, public transportation, hitchhiking, or borrowing a car are not really alternative transportation means. Less than 5 percent of the older citizens used those means of transportation. Furthermore, when one is sixtyfive years or older and living in a rural area walking does not provide a meaningful alternative.

When the means of traveling to town are related to type of household some interesting observations are noted (Table 10, 11, 12, and 13). Among the household heads, practically none hitchhike or rarely borrow a car. Overall, public transportation is not an important mode of transportation for the rural elderly (Table 11). However, for those household heads who are living alone or with relatives it becomes a more meaningful alternative. Walking to town may not be a viable means of getting to town for most of the aged who live in rural areas, but, it is interesting to note that a sizeable proportion of single females do indeed walk to town (Table 13).

From the preceding information it is clear that older citizens who do not drive their own vehicles place considerable reliance upon their children, neighbors, friends, and relatives for transportation needs. It is likely that these informal networks are partially responsible for the absence of transportation problems among the elderly. It is also likely that these means of transport may suffer from stress and instability. Friends and neighbors do not always tolerate the inconvenience, and since the summer of 1978 when the field interviews were conducted, transportation costs have greatly increased. Just because relatives or friends provide the means of transport does not mean that it is costless or that the elderly do not pay for the service. On the contrary, a sizeable number of the elderly either pay for the gas and oil or pay cash to those providing the service (Table 14).

From another perspective, transportation may not be perceived as a problem by those who travel infrequently or not at all. Table 16 shows that approximately two-thirds of the sample travelled to town at least once a week. 


\section{Table 10}

Borrowing Cars and Type of Household for a Sample of Elderly Household Heads in Doddridge, Hampshire, and Webster Counties, West Virginia, 1978.

Type of Household

\begin{tabular}{|c|c|c|c|c|c|c|}
\hline Borrowing a & $\begin{array}{l}\text { Single } \\
\text { ar Male }\end{array}$ & $\begin{array}{l}\text { Single } \\
\text { Female }\end{array}$ & $\begin{array}{l}\text { Aged Head } \\
\text { and Spouse }\end{array}$ & $\begin{array}{l}\text { Aged Head } \\
\text { with Family }\end{array}$ & $\begin{array}{c}\text { Aged Head } \\
\text { with Other } \\
\text { Relatives }\end{array}$ & Totals \\
\hline Usually & 0 & 0 & 2 & 0 & 0 & 2 \\
\hline Sometimes & 1 & 1 & 7 & 2 & 1 & 12 \\
\hline Never & 35 & 83 & 114 & 35 & 43 & 310 \\
\hline Totals & 36 & 84 & 123 & 37 & 44 & 324 \\
\hline
\end{tabular}

Chi square $=6.86$ with 8 degrees of freedom.. significance $=0.454$.

\section{Table 11}

Use of Public Transportation and Type of Household, Sample of Elderly Household Heads in Doddridge, Hampshire, and Webster Counties, West Virginia, 1978.

Type of Household

Single Single Aged Head Aged Head with Transportation Male Female and Spouse with Family Relatives Totals

\begin{tabular}{lrrrrrr}
\hline Usually & 3 & 3 & 1 & 1 & 1 & 9 \\
Sometimes & 3 & 24 & 8 & 2 & 12 & 49 \\
Never & 30 & 57 & 114 & 34 & 31 & 266 \\
$\quad$ Totals & 36 & 84 & 123 & 37 & 44 & 324 \\
\hline
\end{tabular}

Chi square $=34.65$ with 8 degrees of freedom. . . significance $=10.0001$.

One-fourth went to town at least once a month and some 10 percent travel less often than once a month. When the frequency of travel is cross tabulated with the degree of transportation problem, however, there is an indication that those who travel infrequently have more transportation problems (Table 17). Viewed from another perspective it might well be that transportation problems discourage older people and as a result they travel less often than they would if such problems did not exist. In spite of age, older citizens do travel to town and a significant proportion make the trip at least once a week. 


\section{Table 12}

Hitchhiking to Town and Type of Household, Sample of Elderly Household Heads in Doddridge, Hampshire, and Webster Counties, West Virginia, 1978.

Type of Household

\begin{tabular}{|c|c|c|c|c|c|c|}
\hline Hitchhike & $\begin{array}{l}\text { Single } \\
\text { Male }\end{array}$ & $\begin{array}{l}\text { Single } \\
\text { Female }\end{array}$ & $\begin{array}{l}\text { Aged Head } \\
\text { and Spouse }\end{array}$ & $\begin{array}{l}\text { Aged Head } \\
\text { with Family }\end{array}$ & $\begin{array}{c}\text { Aged Head } \\
\text { with Other } \\
\text { Relatives }\end{array}$ & Totals \\
\hline Usually & 0 & 0 & 1 & 0 & 0 & 1 \\
\hline Sometimes & 1 & 3 & 1 & 0 & 1 & 6 \\
\hline Never & 35 & 81 & 121 & 37 & 43 & 317 \\
\hline Totals & 36 & 84 & 123 & 37 & 44 & 324 \\
\hline
\end{tabular}

Chi square $=4.626$ with 8 degrees of freedom. . significance $=0.7967$.

Table 13

Walking to Town and Type of Household, Sample of Elderly Household Heads in Doddridge, Hampshire, and Webster Counties, West Virginia, 1978.

Type of Household

\begin{tabular}{|c|c|c|c|c|c|c|}
\hline Walk & $\begin{array}{l}\text { Single } \\
\text { Male }\end{array}$ & $\begin{array}{l}\text { Single } \\
\text { Female }\end{array}$ & $\begin{array}{l}\text { Aged Head } \\
\text { and Spouse }\end{array}$ & $\begin{array}{l}\text { Aged Head } \\
\text { with Family }\end{array}$ & $\begin{array}{c}\text { Aged Head } \\
\text { with Other } \\
\text { Relatives }\end{array}$ & Totals \\
\hline Usually & 3 & 15 & 4 & 2 & 6 & 30 \\
\hline Sometimes & 5 & 16 & 21 & 6 & 6 & 54 \\
\hline Never & 28 & 53 & 98 & 29 & 32 & 240 \\
\hline Totals & 36 & 84 & 123 & 37 & 44 & 324 \\
\hline
\end{tabular}

Chi square $=15.807$ with 8 degrees of freedom . . significance $=0.0452$.

Among the many reasons why older citizens travel to town, purchasing food and visiting a doctor were considered as establishing the most fundamental needs for transportation in rural areas. Obviously, older citizens have other transportation needs such as paying bills, buying clothes, visitations, etc. While some individuals may not need medical services, it would be rare to find a senior citizen who did not occasionally go to the grocery store. Thus, distance to the grocery store establishes an important benchmark when considering transportation needs of the rural elderly. Further, it would be 


\section{Table 14}

Compensation Given for Riding with Friends, Relatives, and Neighbors, Sample of Elderly Household Heads in Doddridge, Hampshire, and

Webster Counties, West Virginia, 1978.

\begin{tabular}{cr}
\hline Compensation Given & Number \\
Yes & 78 \\
No & 202 \\
Missing & 45 \\
Payment for Gas and Oil & \\
Yes & 47 \\
No & 29 \\
Missing & 249 \\
Cash Instead of Buying Gas or Oil $(\$)$ & \\
1 & 1 \\
2 & 13 \\
3 & 3 \\
4 & 1 \\
5 & 7 \\
6 & 1 \\
8 & 1 \\
10 & 1 \\
20 & 3 \\
\hline
\end{tabular}

Table 15

"If Transportation Poses a Problem for You, How Would you Suggest It Be Resolved?" Sample of Elderly Household Heads in Doddridge, Hampshire, and Webster Counties, West Virginia, 1978.

\begin{tabular}{lcc}
\hline \hline Solution & Number & Percent \\
\hline Rely on children & 4 & 6.1 \\
Rely on neigrivors & 5 & 7.6 \\
Bus & 11 & 16.6 \\
Lower transportation cost & 3 & 4.5 \\
Fix the road & 2 & 3.0 \\
Public transportation & 6 & 9.1 \\
No solution suggested & 35 & 53.0 \\
$\quad$ Total & 66 & 100.0 \\
\hline
\end{tabular}




\section{Table 16}

Frequency of Travel to Town, Sample of Elderly Household Heads in Doddridge, Hampshire, and Webster Counties, West Virginia, 1978.

\begin{tabular}{lrc}
\hline \hline Frequency & Number & Percent \\
\hline At least once daily & 36 & 11.1 \\
At least once weekly & 167 & 51.4 \\
At least once a month & 86 & 26.5 \\
Less often than once a month & 35 & 10.8 \\
Missing & 2 & 0.3 \\
Totals & 325 & 100.0 \\
\hline
\end{tabular}

\section{Table 17}

Frequency of Travel to Town and Incidence of Transportation Problems, Sample of Elderly Persons in Doddridge, Hampshire, and Webster Counties, West Virginia, 1978.

\begin{tabular}{lccccc}
\hline \hline & \multicolumn{5}{c}{ Frequency } \\
\cline { 2 - 6 } Is Transportation & Daily & Weekly & Monthly & $\begin{array}{c}\text { Less Often } \\
\text { than Monthly }\end{array}$ & Totals \\
a Problem? & 1 & 10 & 4 & 5 & 20 \\
\hline Serious problem & 3 & 26 & 32 & 6 & 67 \\
Some problem & 48 & 194 & 93 & 41 & 376 \\
No problem & 52 & 230 & 129 & 52 & 463 \\
\hline Totals & 52 &
\end{tabular}

Chi square $=21.08$ with 8 degrees of freedom. . significance $=0.0018$.

expected that as the distance increased so would one's perception of transportation problems. The data in Table 18 indicate that a third of the respondents lived within two miles of a grocery store and two-thirds lived within ten miles. However, the data in Table 19 do not support a relationship between distance and transportation problems. There appear to be more total problems with transportation as distance increases beyond $1 \frac{1}{2}$ miles but the proportion of respondents who indicate no problems remains almost constant for those who live within $1 \frac{112}{2}$ miles and those who live $11+$ miles from the grocery store (Table 20 ).

From the preceding information it was hypothesized that those who do not drive, those who live in rural areas, and those who do not own a car would have a higher incidence of transportation problems. As expected, the cross tabulations between car ownership and problems indicated that those without 


\section{Table 18}

Distance to Grocery Store, Sample of Elderly Household Heads in Doddridge, Hampshire, and Webster Counties, West Virginia, 1978.

\begin{tabular}{lcc}
\hline \hline Distance & Number & $\begin{array}{c}\text { Cummulative } \\
\text { Percent }^{\star}\end{array}$ \\
\hline Up to one mile & 51 & 21.2 \\
One to two miles & 27 & 32.4 \\
Two to five miles & 27 & 43.6 \\
Five to ten miles & 58 & 67.6 \\
Ten to fifteen miles & 55 & 90.5 \\
Fifteen or more miles & 23 & 100.0 \\
Unsure of mileage & 84 & - \\
& 325 & \\
\hline
\end{tabular}

"Excluding those who were unsure of the mileage.

Table 19

Incidence of Transportation Problems in Miles to Grocery Store, Sample of Elderly Household Heads in Doddridge, Hampshire, and Webster Counties, West Virginia, 1978.

\begin{tabular}{|c|c|c|c|c|c|c|c|c|}
\hline \multirow{3}{*}{$\begin{array}{l}\text { Incidence of } \\
\text { Transportation } \\
\text { Problems }\end{array}$} & \multicolumn{8}{|c|}{ Distance to Grocery Store } \\
\hline & \multicolumn{2}{|c|}{$\begin{array}{l}\text { Up to } \\
\text { 1.4 Miles }\end{array}$} & \multicolumn{2}{|c|}{$\begin{array}{l}1.5 \text { Miles to } \\
5.9 \text { Miles }\end{array}$} & \multicolumn{2}{|c|}{$\begin{array}{l}\text { 6.0 Miles to } \\
10 \text { Miles }\end{array}$} & \multicolumn{2}{|c|}{$\begin{array}{l}11^{+} \\
\text {Miles }\end{array}$} \\
\hline & No. & $\%$ & No. & $\%$ & No. & $\%$ & No. & $\%$ \\
\hline $\begin{array}{l}\text { Serious problem } \\
\text { Some problem }\end{array}$ & $\begin{array}{r}3 \\
13\end{array}$ & $\begin{array}{r}3 \\
12\end{array}$ & $\begin{array}{r}7 \\
15\end{array}$ & $\begin{array}{l}10 \\
22\end{array}$ & $\begin{array}{r}6 \\
10\end{array}$ & $\begin{array}{r}7 \\
12\end{array}$ & $\begin{array}{r}4 \\
29\end{array}$ & $\begin{array}{r}2 \\
14\end{array}$ \\
\hline No problem & 92 & 85 & 45 & 68 & 67 & 81 & 172 & 84 \\
\hline
\end{tabular}

cars had a high and significant incidence of transportation problems when compared to those with cars (Table 21). One could reasonably conclude that cars are indeed essential in rural areas not served by public transportation and in areas where there are but few widely scattered residences. Further, there must be an element of fear among those who live in remote areas without a car. How do you get to town if an emergency arises? Earlier it was noted that inability to drive was a major factor listed by those who do not own a car. Table 22 indicates that transportation problems are restricted largely to those who do not drive. 


\section{Table 20}

Distance to Grocery Store and Incidence of Transportation Problems, Sample of Elderly Persons in Doddridge, Hampshire, and Webster Counties, West Virginia, 1978.

\begin{tabular}{|c|c|c|c|c|}
\hline \multirow[b]{2}{*}{$\begin{array}{l}\text { Is Transportation } \\
\text { Problem? }\end{array}$} & \multicolumn{4}{|c|}{ Distance to Store } \\
\hline & $\begin{array}{l}\text { Up to } \\
1.5 \text { Miles }\end{array}$ & $\begin{array}{l}1.5 \text { Miles to } \\
5.9 \text { Miles }\end{array}$ & $\begin{array}{l}6.0 \text { Miles to } \\
9.9 \text { Miles }\end{array}$ & $11+$ Miles \\
\hline Serious problem & 3 & 7 & 6 & 4 \\
\hline Some problem & 13 & 15 & 10 & 29 \\
\hline No Problem & 92 & 45 & 67 & 172 \\
\hline Totals & 106 & 67 & 83 & 205 \\
\hline
\end{tabular}

Table 21

Car Ownership and Incidence of Transportation Problems, Sample of Elderly Persons in Doddridge, Hampshire, and Webster Counties, West Virginia, 1978.

\begin{tabular}{|c|c|c|c|c|c|c|}
\hline \multirow{3}{*}{$\begin{array}{l}\text { Is Transportation } \\
\text { to Town a Problem? }\end{array}$} & \multicolumn{6}{|c|}{ Car Ownership } \\
\hline & \multicolumn{2}{|c|}{ Yes } & \multicolumn{2}{|c|}{ No } & \multicolumn{2}{|c|}{ Totals } \\
\hline & No. & $\%$ & No. & $\%$ & No. & $\%$ \\
\hline Serious problem & 3 & 1.9 & 17 & 10.5 & 20 & 6.2 \\
\hline Some problem & 15 & 9.3 & 52 & 32.1 & 67 & 20.7 \\
\hline No problem & 144 & 88.8 & 93 & 57.4 & 237 & 73.1 \\
\hline Totals & 162 & 100.0 & 162 & 100.0 & 324 & 100.0 \\
\hline
\end{tabular}

Chi square $=37.71553$ with 2 degrees of freedom. . significance $=0.0001$.

\section{Summary, Conclusions and Speculations}

According to the U.S. Senate report, Transportation in Rural America, rural transportation systems incur high costs because of low population densities, low ridership, and relatively high costs for equipment and operations. As a result, bus and taxi services in rural areas have seriously declined over the past twenty years. Efforts have been made by agencies at each level of government to support rural transportation but the results have not been very encouraging. Currently, there is not an integrated network of publicly subsidized rural transportation systems.

The transportation needs and problems of older citizens often have been cited as partial justification for publicly supported rural transportation systems. The demographic data indicate that persons 65 years of age or older 
Table 22

Reasons for not Driving Cars and Incidence of Transportation Problems, Sample of Elderly Persons in Doddridge, Hampshire, and Webster Counties, West Virginia, 1978.

\begin{tabular}{lcccc}
\hline \hline & \multicolumn{4}{c}{ Why no Car } \\
\cline { 2 - 5 } $\begin{array}{l}\text { Is Transportation } \\
\text { a Problem? }\end{array}$ & $\begin{array}{c}\text { Too } \\
\text { Expensive }\end{array}$ & $\begin{array}{c}\text { Do Not } \\
\text { Drive }\end{array}$ & $\begin{array}{c}\text { Other } \\
\text { Reasons }\end{array}$ & Totals \\
\hline Serious problem & 2 & 10 & 3 & 15 \\
Some problem & 4 & 38 & 9 & 51 \\
No Problem & 4 & 104 & 44 & 152 \\
$\quad$ Totals & 10 & 152 & 56 & 218 \\
\hline
\end{tabular}

comprise a relatively high proportion of the rural population, but numbers alone do not establish the need for rural transportation for senior citizens. The analysis of data from personal interviews with older people in three rural counties of West Virginia indicates that relatively few of the elderly, 20 percent, perceive any transportation problems. When the results are categorized by sex, there is clear indication that older females have more transportation problems than older males.

Further refinement of the data shows that the absence of transportation problems among the elderly is related to the high proportion who furnish their own transportation or who use informal transportation networks. In the first instance approximately one-half of those interviewed drove their own cars and in the second instance a third of the respondents relied upon family members, relatives, and friends for their transportation needs. Car ownership is relatively high among senior citizens in rural areas and the inability to drive is the most important reason for not owning a car. Transportation problems increase among those who do not drive, and it is this group of elderly citizens who have a greater dependence upon relatives and friends for the provision of transportation services.

Less than 5 percent of those interviewed usually used public transportation to travel to town. Almost 10 percent walked to town and 1 percent borrowed a car or hitchhiked.

Transportation problems are related to type of household. In those households with a husband and wife, fewer transportation problems were indicated. Transportation problems increased in those households where a single male or single female lived alone; this was especially true among females.

From time to time there is public discussion of driving ability of older aged individuals. Some people note that as people get older their reflexes are slower, their eyesight grows dimmer, their hearing becomes more impaired, etc., and these age-related debilities adversely affect their driving ability. In general, those who hold these opinions would prohibit elderly people from driving after reaching a specific age or require them to take periodic tests to 
assess their driving skills for license renewal. Another group notes that traffic accidents are highest among individuals under thirty and if driving tests are necessary, they also should be mandated for the younger-age groups. The data from this study cannot be used to assess these different opinons, but one does discern that a high proportion of the elderly do not drive, and as a result do not own cars, and that about half of the elderly provide their own transportation. In view of limited transport systems in rural areas any program which attempted to significantly reduce the number of senior citizens who drive their own cars would meet considerable resistance. In addition, public transport systems would likely be demanded from the political system if any attempt were made to require special examinations for those beyond a given age of, say, 65 .

The informal transportation networks that were uncovered in this research deserve special mention. First, they are quite important to senior citizens in rural areas and in many instances represent the only means of "getting out of the hollow and into town." A third of those interviewed usually relied upon this privately supported transportation system and another large group sometimes used such networks. Second, the costs for these systems are being borne by private individuals rather than public coffers. Third, these systems do provide social contact for the elderly and another means of interacting with a larger society. Fourth, these informal networks are utilized to the greatest extent by single females living alone and heads of households who live with non-filial relatives and friends. Fifth, it would seem appropriate that in the formation of public policy regarding transportation, some consideration be given to a more equitable distribution of the costs of these informal transportation networks used by senior citizens.

Apparently there is something more involved than the simple provision of transport services under these private, voluntary arrangements between older citizens and their children, neighbors, friends, and relatives. One suspects that these arrangements offer yet another opportunity for the elderly to visit with their children or to interact with neighbors and friends. It is these human bonds of friendship and neighborliness that may lead so many to note that they have no transportation problems.

Even arnong those who indicated transportation problems, a sizeable proportion viewed the informal transportation networks as the solution to their problems, rather than public transportation (Table 15). One could speculate that public transportation is viewed as a competitor with these interpersonal relationships and might not be welcomed. After all, the interaction during a trip to town in a neighbor's car provides real human needs for conversation, human expression, socializing, and simply contact with other people. With a third of the sample usually using this form of transportation and 80 percent of the remainder sometimes using these informal networks it is obvious that they are tremendously important in rural West Virginia.

In conclusion, this research effort indicates that half of our elderly citizens in rural areas provide their own transportation, a third use the time and resources of relatives and friends, 5 percent use public transportation, and the remainder live close enough to walk into town or else they seldom go to town. Problems with transportation are greatest among those who do not drive, single females living alone, and elderly household heads who live with non-filial relatives. 